\title{
Daily intake of conjugated linoleic acid-enriched yoghurts: effects on energy metabolism and adipose tissue gene expression in healthy subjects
}

\author{
Julie-Anne Nazare $^{1}$, Aude Brac de la Perrière ${ }^{1}$, Fabrice Bonnet ${ }^{1}$, Michel Desage ${ }^{1}$, Jocelyne Peyrat ${ }^{1}$, \\ Christine Maitrepierre ${ }^{1}$, Corinne Louche-Pelissier ${ }^{1}$, Joëlle Bruzeau ${ }^{1}$, Joëlle Goudable ${ }^{1}$, Taous Lassel ${ }^{2}$, \\ Hubert Vidal ${ }^{1}$ and Martine Laville ${ }^{1 *}$ \\ ${ }^{1}$ Centre de Recherche en Nutrition Humaine de Lyon, Université Claude Bernard Lyon 1; INSERM U449; INRA 1235; Hospices \\ Civils de Lyon, Place D'Arsonval, 69003 Lyon, France \\ ${ }^{2}$ Danone Vitapole, $R D$ 128, 91767 Palaiseau, France
}

(Received 13 January 2006 - Revised 28 June 2006 - Accepted 28 June 2006)

\begin{abstract}
Conjugated linoleic acid (CLA) is a group of positional and geometric isomers of conjugated dienoic derivatives of linoleic acid. The present study was designed to determine whether 14-week CLA supplementation as triacylglycerols $(3.76 \mathrm{~g})$ with a $50: 50$ combination of the two main isomers (35\% cis-9,trans-11 and $35 \%$ trans-10,cis-12) added to flavoured yoghurt-like products was able to alter body composition in healthy subjects and to alter the expression of several key adipose tissue genes (PPAR $\gamma$, lipoprotein lipase (LPL), hormone-sensitive lipase (HSL) and uncoupling protein 2 (UCP-2)). Forty-four healthy subjects were randomly assigned to consume daily either a CLA-supplemented yoghurt-like product or a placebo yoghurt for $98 \mathrm{~d}$. There were no significant effects of CLA supplementation on body weight, fat mass or free fat mass. Basal energy expenditure expressed as $\mathrm{kg}$ free fat mass increased significantly in the CLA group (123.3 (SEM 2.5) $\mathrm{kJ} / \mathrm{kg}$ free fat mass per $\mathrm{d}$ on day $98 \mathrm{v}$. 118.7 (SEM 2.3 ) $\mathrm{kJ} / \mathrm{kg}$ free fat mass per $\mathrm{d}$ on day $0, P=0.03$ ). PPAR $\gamma$ mRNA gene expression increased significantly with CLA supplementation (53 (SEM 20) \%, P<0.01) and a significant reduction in mRNA levels of HSL was observed ( -42 (SEM 7) \%, $P=0 \cdot 01$ ). The levels of UCP-2 and LPL mRNA were not affected. The present results suggest that a $98 \mathrm{~d}$ supplementation diet with a 50:50 mixture of the two CLA isomers cis-9,trans-11 and trans-10,cis-12 in a dairy product was unable to alter body composition, although a significant increase in the RMR has been induced. Moreover, changes in mRNA PPAR $\gamma$ and HSL in adipose tissue were recorded.
\end{abstract}

Conjugated linoleic acid: Energy metabolism: Adipose tissue gene expression

Conjugated linoleic acid (CLA) is a group of positional and geometric isomers of conjugated dienoic derivatives of linoleic acid. The cis-9,trans-11 isomer of CLA, also known as rumenic acid, accounts for $>90 \%$ of the total CLA intake and is mostly found in beef and dairy products (Lin et al. 1995). Other minor isomers are also detected in the human diet in smaller proportions. Recent studies investigating the health benefits of CLA isomers focused on their anticarcinogenic and antiatherogenic properties, as well as on their ability to reduce body fat and enhance lean body mass in several animal models (Dugan et al. 1997; Park et al. 1999; Blankson et al. 2000; DeLany \& West, 2000; Kritchevsky et al. 2000; Pariza et al. 2000; Stangl, 2000; Zambell et al. 2000; Terpstra et al. 2002; Wang \& Jones, 2004). These latter properties may suggest that CLA supplementation could have beneficial effects on the management of body weight in man and therefore on the treatment and prevention of obesity. Postulated anti-obesity mechanisms of CLA are decreased energy and food intakes, decreased lipogenesis, and increased energy expenditure, lipolysis and fat oxidation (West et al. 1998; Takahashi et al. 2002; Wang \& Jones, 2004).
All these mechanisms generally rely on the regulation of the expression of the key proteins of energy metabolism. Accordingly, CLA has been shown to modulate adipocyte gene expression in several animals and in vitro models (Ryder et al. 2001; Takahashi et al. 2002; Brown \& McIntosh, 2003; Brown et al. 2003; Grandlund et al. 2003; Kang et al. 2003; Park et al. 2004; Wargent et al. 2005). Among the genes that appeared to be relevant for the effects of CLA, the PPAR are ligand-activated nuclear hormone receptors that control the expression of sets of genes involved in cellular metabolism and differentiation. It has been reported that CLA isomer trans-10,cis-12 could inhibit PPAR $\gamma$ expression and some of its downstream target genes (LPL, GLUT4, aP2) in rodent adipocytes (Brown \& McIntosh, 2003). Furthermore, Kang et al. (2003) have also shown that CLA decreases body fat gain and significantly inhibits the expression of PPAR $\gamma$ and the differentiation into mature adipocytes. However, their results were not consistently found and other investigators have observed an increase in PPAR $\gamma$ gene expression by CLA cis-9,trans-11 (Brown et al. 2003). In another study, it was shown that a mixture of the two CLA isomers induces an up-regulation of uncoupling

\footnotetext{
Abbreviations: CLA, conjugated linoleic acid; HSL, hormone-sensitive lipase; LPL, lipoprotein lipase; UCP-2, uncoupling protein 2.

* Corresponding author: Prof. M Laville, Centre de Recherche en Nutrition Humaine de Lyon, Hôpital E Herriot, Place d'Arsonval, 69003 Lyon, France, Fax + 33 4780098 98, email martine.laville@chu-lyon.fr
} 
protein 2 (UCP-2) gene expression, a target gene of the PPAR, in rat skeletal muscle and adipose tissue (Ryder et al. 2001).

Up to now, several human studies have been published but the effects of CLA consumption were rather inconsistent and appeared less important than what was expected from animal studies (Blankson et al. 2000; Zambell et al. 2000; Smedman \& Vessby, 2001; Kamphuis et al. 2003; Riserus et al. 2004; Terpstra et al. 2004; Desroches et al. 2005; Tricon et al. 2005). For example, Blankson et al. (2000) reported a reduction in the fat mass of overweight and obese subjects after 12 weeks of supplementation with CLA $(3.4 \mathrm{~g} / \mathrm{d})$ divided into three doses per day. Desroches et al. (2005) failed to show any beneficial metabolic effects and no differences were observed in the accumulation of adipose tissue compared with placebo after 4 weeks of supplementation with CLA incorporated into butter (4.22 g CLA/100 g butter) in overweight and obese subjects. In lean women, Zambell et al. (2000) observed that supplementation of the diet with $3 \mathrm{~g} / \mathrm{d}$ of CLA for 9 weeks had no effect on body composition and energy expenditure. The potential action of CLA on adipose tissue gene expression in man during dietary supplementation has not yet been investigated.

The aim of the present study was to determine whether 14-week CLA supplementation as triacylglycerols (3.76 g) with a 50:50 combination of the two main isomers (cis9,trans-11 and trans-10,cis-12) added to flavoured yoghurtlike products was able to alter body composition in healthy human adults. And in addition, subcutaneous abdominal adipose tissue biopsies were performed to investigate in vivo the changes in the expression of several key adipose tissue genes, including PPAR $\gamma$, lipoprotein lipase (LPL), UCP-2 and hormone-sensitive lipase (HSL).

\section{Material and methods}

\section{Material}

The yoghurt-like products were made using a standard dairy process for fermented milk. They were made of skimmed milk inoculated with $10^{7}$ colony-forming units of yoghurt bacillus (Streptococcus thermophilus, Lactobacillus bulgaricus), $8 \%$ sugar, cherry flavour and $3.76 \mathrm{~g}$ triacylglycerols TONALIN $75 \mathrm{TG}^{\circledR}$ for the CLA group and cream for the control group. To maintain a similar isoenergetic composition, the same amount of fat was used. The CLA mixture contained $35 \%$ cis-9,trans-11 isomer and 35\% trans-10,cis-12 isomer. The major remaining fatty acids were $8.3 \%$ C16-0, $2.9 \%$ C18-0, $14.8 \%$ 18: $1 n-9$ and $1.4 \%$ 18: $2 n-6$. Less than $1 \%$ of trans-trans CLA isomers were found. This composition has been verified by GC-MS as described later. The yoghurt-like products were produced and delivered by Danone Company, Palaiseau, France. TONALIN 75 TG $^{\circledR}$ was supplied by Natural Lipids Ltd (Hovdebygda, Norway).

\section{Study subjects}

Forty-four healthy volunteers, twenty-two women and twentytwo men with a mean age of 28.9 (SEM 1.14) years, moderately overweight mean weight of 72.5 (SEM 1.17 ) $\mathrm{kg}$, with a mean BMI of $25 \cdot 2$ (SEM 0.21$) \mathrm{kg} / \mathrm{m}^{2}$ were recruited from the local community by advertisement.
All subjects gave written informed consent to participate and complied with the following inclusion criteria: BMI $23-27.5 \mathrm{~kg} / \mathrm{m}^{2}$ with a stable body weight for at least 3 months; having at least $135 \mathrm{~min}$ of moderate exercise per week; fasting plasma cholesterol $<6.5 \mathrm{mmol} / \mathrm{l}$; fasting plasma triacylglycerol $<2 \mathrm{mmol} / \mathrm{l}$; fasting plasma glucose $<7 \mathrm{mmol} /$ 1 ; not regular consumers of any fatty acid nutritional supplements or drugs known to affect body weight, lipid or glucose metabolism except for oral contraceptive for women. Pregnant women were not allowed to be part of this protocol.

The present study was approved by the Ethics Committee of the Hospices Civils de Lyon.

\section{Study design}

This was a randomised double-blind placebo-controlled study. Subjects were randomly assigned to receive either CLA-supplemented yoghurt-like products (CLA group, $n$ 21) or placebo yoghurts (placebo group, $n$ 23). Subjects were instructed to consume one yoghurt daily, at the end of their usual breakfast, for 14 weeks (98d). Subjects maintained their usual dietary habits during the study and were asked to have regular physical activity ( $45 \mathrm{~min}$, three times per week) and to hold a physical activity diary that was checked every 2 weeks. Subjects came to the Centre de Recherche en Nutrition Humaine de Lyon, at Hôpital Edouard Herriot, for blood sampling at 07.30 hours following a $12 \mathrm{~h}$ overnight fast, on days 0,42 and 98 .

\section{Body composition and laboratory methods}

At each visit, evaluation criteria were measured. After urine collection, weight was measured on a carefully calibrated scale (SECA, Les Mureaux, France). Height was measured using a calibrated height gauge. Total lean body mass and total fat mass were measured using a dual-energy X-ray absorptiometer (Hologic QDR 4500 A; Hologic Inc., Waltham, MA, USA) on the first (day 0) and on the last (day 98) visits. Blood samples were drawn for measurement of glycaemia, insulinaemia, triacylglycerols, NEFA, total and HDL cholesterol, liver enzymes, blood cell count, bleeding time, prothrombin, activated cephalin time, thiobarbituric acid reactive substances, CLA and fatty acid profile.

On days 0 and 98, subcutaneous abdominal adipose tissue biopsies were performed under local anaesthesia by aspiration from the per-umbilical area through a 15-gauge needle, as previously described (Vidal et al. 1996). Tissue samples were immediately frozen in liquid nitrogen and stored at $-80^{\circ} \mathrm{C}$ for later analysis. Respiratory exchange measurements were performed during a $1 \mathrm{~h}$ period by indirect calorimetry (Deltatrac Metabolic Monitor; Datex, Helsinki, Finland). Urine was collected during the calorimetry measurements to determine the nitrogen excretion rate. Total lipid oxidation rate and RMR were calculated as previously described (Binnert et al. 1998).

Plasma glucose, triacylglycerols and NEFA concentrations were measured by enzymatic methods. Plasma insulin was measured by RIA as previously described (Binnert et al. 1998). Blood cell counts, liver enzymes and activated cephaline time were determined using standard methods. Urinary nitrogen was determined by chemioluminescence (Antek 
703C; Sopares, Paris, France). Lipid peroxidation was quantified through fluorometric measurements of thiobarbituric acid reactive substances (Richard et al. 1992).

Plasma fatty acids and CLA isomer concentrations (cis-9, trans-11 and trans-10,cis-12) were measured by GC-MS after extraction and esterification by the method of Bligh \& Dyer (1995) and purification by TLC (hexane-diethyl ether-acetic acid, 80:20:1, by vol.). Precautions were taken for preventing the possible isomerisation of CLA into trans, trans isomers (Fay \& Richli, 1991), the absence of such isomers was checked at each analysis. Fatty acid methyl esters were separated by GC (capillary column, HP Innowax $60 \mathrm{~m} \times 0.25 \mathrm{~mm} \times 0.25 \mu \mathrm{m})$ and analysed by MS using a HP-5973 and Specific Ion Monitoring for CLA measurements (Lavillonnière et al. 1998).

\section{Total RNA preparation}

For practical purposes, RNA preparations were only made from the biopsies of twenty-two subjects from a random sub-selection: eleven subjects in the placebo group (six men and five women) and eleven subjects in the CLA group (five men and six women). One biopsy from one subject from the CLA group was not usable. Analysis was always doubleblindly performed. Adipose tissue samples were pulverized in liquid nitrogen and total RNA was prepared using the Qiagen (Courtaboeuf, France) RNeasy total RNA kit. Average yields of total RNA were 1.2 (SEM 0.2) $\mu \mathrm{g} / 100 \mathrm{mg}$ adipose tissue (wet weight). Total RNA solutions were stored at $-80^{\circ} \mathrm{C}$ until quantification of the target mRNA.

\section{Determination of $m R N A$ concentrations}

We measured the steady-state expression level of mRNA encoding HSL, LPL, UCP-2 and PPAR $\gamma$. The concentrations of the target mRNA were measured by RT-competitive PCR. The method relies on the addition of known amounts of a competitor DNA molecule in the PCR to standardize the amplification process (Auboeuf \& Vidal, 1997). The construction of the competitors, the sequences of the primers, the validation of the assays and the conditions of the RT-competitive PCR assays have previously been described in full detail (Laville et al. 1996; Vidal et al. 1996; Auboeuf \& Vidal, 1997; Lefebvre et al. 1998). For each mRNA, the specific first strand cDNA was synthetized from $0 \cdot 1 \mu \mathrm{g}$ total RNA in the presence of the specific antisense primer and a thermostable RT enzyme to guarantee optimal synthesis of first strand cDNA (Auboeuf \& Vidal, 1997). Cy-5-5'-end labelled sense primers that were used during the competitive PCR products were analysed using an automated laser fluorescence DNA sequencer (ALFexpress, Pharmacia, Uppsala, Sweden) in $4 \%$ denaturing polyacrylamide gels.

\section{Statistical analysis}

All results are given as means and their standard errors. Differences between groups from baseline to day 98 were assessed using overall tests. In the case of a significant overall test result, a Wilcoxon non-parametric test was used for differences between groups.
An interaction test was used to determine the effects of CLA, sex, type of subject (fat or lean) and the interactions CLA $\times$ sex and CLA $\times$ type of subject on body composition.

According to prior work (Blankson et al. 2000), it was estimated that twenty subjects per group would be needed to detect a $5 \%$ change in body fat mass levels at a significant level of 0.05 using a power of 0.85 and a standard deviation of 6 .

All analyses were performed using Statview version 5.0 software (SAS Institute, Cary, NC, USA).

\section{Results}

Baseline status, compliance and tolerance

Baseline characteristics were similar in both groups (Table 1) and also in the subgroup chosen for biopsy (data not shown). All of the forty-four subjects completed the study. CLAenriched products were well tolerated as no adverse events occurred. Compliance was excellent $(99.9 \%)$, using a product count every 2 weeks on the occasion of each yoghurt-like product delivery.

\section{Blood parameters}

Regarding blood parameters, no changes were observed in blood cell count, liver enzyme levels, bleeding time and prothrombin concentration (data not shown). However, activated cephalin time was significantly increased in men from the CLA group (33.6 (SEM 1.1) and 34.4 (SEM 1.4) s, on day 0 and day 98 , respectively, $P=0.01)$ but not in women $(31 \cdot 1$ (SEM 0.8) and 31.0 (SEM 1.2) s, on day 0 and day 98, respectively, NS). Thiobarbituric acid reactive substance formation was unaltered by CLA consumption, in men (3.37 (SEM 0.08 ) and $3.03(\operatorname{SEM~} 0 \cdot 10) \mathrm{mol} / \mathrm{l}$, at day 0 and day 98 , respectively) and in women (3.65 (SEM 0.16) and 3.34 (SEM 0.17) $\mathrm{mol} / \mathrm{l}$, at day 0 and day 98 ) from the CLA group.

\section{Body composition, plasma lipids, glucose, insulin and leptin}

The consumption of CLA-enriched yoghurt-like products for 14 weeks (98d) affected neither the body weight nor the BMI of the subjects (Table 1), whether in male or in female (data not shown). Similarly, fat mass and free fat mass, determined by a dual-energy X-ray absorptiometer, were not modified by the CLA supplementation diet (Table 1) and there was also no effect of sex or type of subject (fat or lean) using an interaction test (data not shown). In addition, no changes occurred in any of the anthropometric parameters that were measured on day 42 of the protocol (data not shown). The consumption of CLA-enriched yoghurt-like products over 14 weeks did not alter any of the following metabolic parameters: glycemia, insulinemia, leptinemia, triacylglycerols, total and HDL-cholesterol concentrations (Table 1). Plasma NEFA concentrations were also left unchanged (Table 1).

Fatty acid composition of total lipids in plasma and adipose tissue

The evolution of CLA cis-9,trans-11 and CLA trans-10,cis-12 concentrations is presented in Fig. 1. Plasma CLA cis-9, trans-11 levels increased with CLA consumption (29.9 (SEM 
Table 1. Effect of dietary supplementation with conjugated linoleic acid (CLA) versus placebo on body composition and metabolic parameters from baseline (day 0) to day 98 (there were no differences between groups at baseline) $\dagger$

(Mean values with their standard errors)

\begin{tabular}{|c|c|c|c|c|c|c|c|c|}
\hline & \multicolumn{4}{|c|}{ Placebo } & \multicolumn{4}{|c|}{ CLA } \\
\hline & \multicolumn{2}{|c|}{ Day $0(n 23)$} & \multicolumn{2}{|c|}{ Day 98 (n 23) } & \multicolumn{2}{|c|}{ Day 0 (n 21) } & \multicolumn{2}{|c|}{ Day 98 (n 21) } \\
\hline & Mean & $\overline{\text { SEM }}$ & Mean & $\overline{S E M}$ & Mean & $\overline{S E M}$ & Mean & $\overline{\text { SEM }}$ \\
\hline Age & 28.5 & 1.14 & - & & 29.4 & 1.39 & - & \\
\hline BMI $\left(\mathrm{kg} / \mathrm{m}^{2}\right)$ & $25 \cdot 1$ & 0.29 & 24.9 & 0.29 & $25 \cdot 2$ & 0.26 & $25 \cdot 6$ & 0.26 \\
\hline Weight (kg) & 71.5 & 1.5 & 72 & 1.6 & 72.5 & 1.8 & $74 \cdot 1$ & 1.9 \\
\hline Fat mass $(\mathrm{kg})$ & $19 \cdot 4$ & 1.2 & $18 \cdot 9$ & 1.3 & $18 \cdot 2$ & $1 \cdot 1$ & $18 \cdot 2$ & $1 \cdot 2$ \\
\hline Free fat mass $(\mathrm{kg})$ & 52.9 & $2 \cdot 0$ & 53.7 & $2 \cdot 1$ & $56 \cdot 1$ & $2 \cdot 3$ & $56 \cdot 7$ & $2 \cdot \overline{2}$ \\
\hline Glycaemia $(\mathrm{mmol} / \mathrm{l})$ & 5 & 0.08 & 5 & 0.06 & 5 & 0.08 & 5 & 0.06 \\
\hline Insulinaemia (mU/l) & 12.9 & 1.12 & 10 & 0.91 & 11.5 & 0.96 & $10 \cdot 2$ & 1.28 \\
\hline Leptinaemia (mg/l) & $11 \cdot 2$ & $2 \cdot 0$ & $10 \cdot 9$ & 1.8 & $9 \cdot 0$ & $1 \cdot 3$ & 9.5 & 1.5 \\
\hline NEFA $(\mu \mathrm{mol} / \mathrm{l})$ & $415 \cdot 13$ & 27 & 385 & 29 & 399 & 47 & 388 & 32 \\
\hline Triacylglycerols $(\mathrm{mmol} / \mathrm{l})$ & 0.87 & 0.06 & 0.94 & 0.08 & 0.88 & 0.05 & 1.05 & 0.09 \\
\hline Total cholesterol $(\mathrm{mmol} / \mathrm{l})$ & 4.55 & 0.17 & 4.56 & 0.16 & 4.63 & $0 \cdot 16$ & 4.59 & 0.19 \\
\hline HDL cholesterol (mmol/l) & 1.38 & 0.07 & 1.52 & 0.08 & 1.33 & 0.06 & 1.38 & 0.08 \\
\hline Lipid oxidation rate (mg/kg per min) & 0.58 & 0.07 & 0.65 & 0.05 & 0.58 & 0.07 & 0.68 & 0.06 \\
\hline Basal energy expenditure ( $\mathrm{kJ} / \mathrm{kg}$ per $\mathrm{d})$ & $88 \cdot 6$ & 1.3 & 88.6 & 1.7 & 89.5 & 1.8 & $93 \cdot 2^{*}$ & 1.9 \\
\hline $\begin{array}{l}\text { Basal energy expenditure }(\mathrm{kJ} / \mathrm{kg} \text { free fat } \\
\text { mass per d) }\end{array}$ & $121 \cdot 6$ & $2 \cdot 3$ & $120 \cdot 4$ & $2 \cdot 2$ & $118 \cdot 7$ & $2 \cdot 3$ & $123 \cdot 3^{\star \star}$ & 2.5 \\
\hline
\end{tabular}

Mean values were significantly different from those of day $0:{ }^{\star} P=0.07 ;{ }^{\star \star} P=0.03$

†For details of procedures, see Materials and methods section.

$3 \cdot 1)$ and $57 \cdot 3($ SEM 7.2) $\mu \mathrm{mol} / 1$, on day 0 and day 98 , respectively, $P<0.02$ ) whereas concentrations remained stable in the
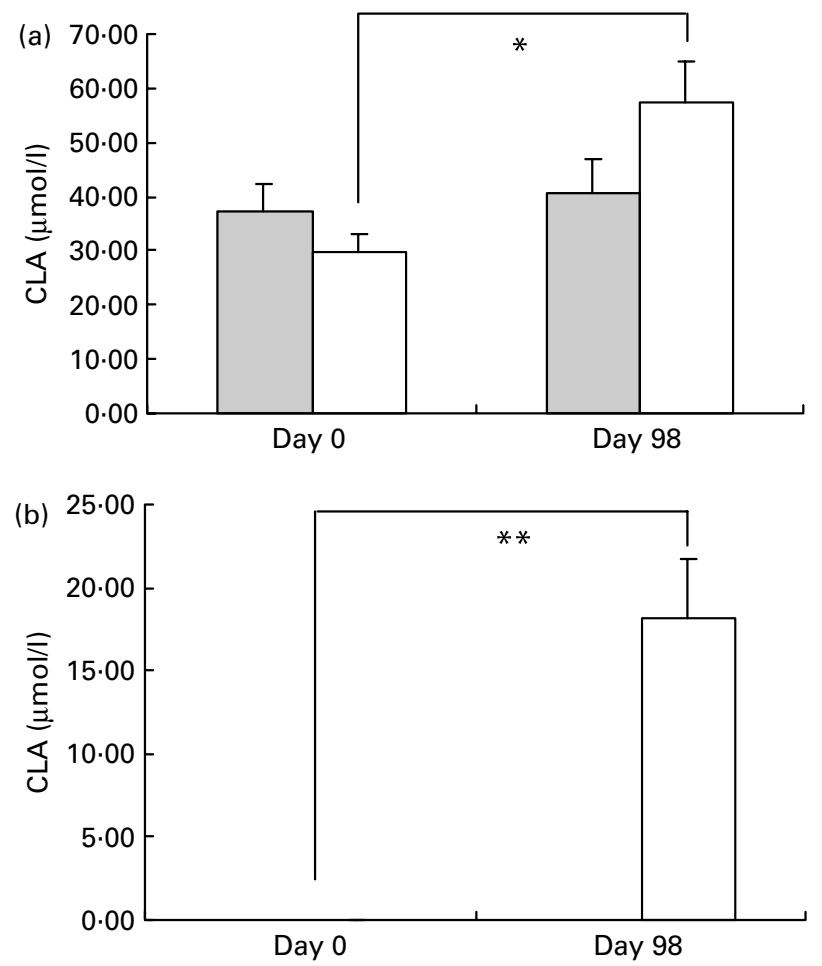

Fig. 1. Evolution of conjugated linoleic acid (CLA) isomers cis-9,trans-11 (a) and trans-10,cis-12 (b) in plasma before (day 0) and after (day 98) supplementation in the placebo ( $\square$ ) and CLA groups ( $\square$ ). For details of procedures, see Materials and methods section. Values are means with their standard errors depicted by vertical bars. There were no differences between groups at baseline. Mean values indicated were significantly different: ${ }^{\star} P<0.02 ;{ }^{\star \star} P<0.01$ placebo group (37.2 (SEM 3.6) and 40.8 (SEM 3.4) $\mu \mathrm{mol} / \mathrm{l}$, on day 0 and day 98 , respectively).

CLA trans-10,cis-12 isomer was undetectable in plasma during the whole study in the placebo group while it increased significantly in the CLA-treated group (undetectable on day 0 and 18.2 (SEM 3.6) on day 98, $P<0 \cdot 01$ ).

The CLA supplementation diet did not alter the relative concentration of $n-3$ or $n-6$ PUFA in plasma NEFA. Values in the CLA group were similar to those in the placebo group (data not shown).

In adipose tissue, CLA trans-12,cis-10 isomer was undetectable in both groups on day 0 and remained undetectable in the placebo group on day 98 but increased significantly in the CLA group from 0 to 1.96 (SEM 0.4) nmol/mg. CLA cis9,trans-11 isomer increased significantly from $8 \cdot 26$ (SEM $0 \cdot 5$ ) to $10 \cdot 47$ (SEM 0.9) $\mathrm{nmol} / \mathrm{mg}(P=0 \cdot 01)$ in the CLA group between day 0 and day 98 but remained stable in the placebo group.

\section{Effects of conjugated linoleic acid supplementation on energy expenditure}

Total lipid oxidation rates were affected by CLA consumption (0.68 (SEM 0.06) $\mathrm{mg} / \mathrm{kg}$ per min $v .0 .58$ (SEM 0.07) $\mathrm{mg} / \mathrm{kg}$ per min on day 98 and day 0 , respectively; Table 1). When referred to total body weight, basal energy expenditure tended to increase more in the CLA group (93.2 (SEM 1.9) $\mathrm{kJ} / \mathrm{kg}$ per d on day $98 v$. 89.5 (SEM 1.8 ) $\mathrm{kJ} / \mathrm{kg}$ per d on day $0, P=0.07)$, whereas no changes were observed in the placebo group (88.6 (SEM 1.7$) \mathrm{kJ} / \mathrm{kg}$ per d at day 98 v. 88.6 (SEM 1.3 ) $\mathrm{kJ} / \mathrm{kg}$ per $\mathrm{d}$ at day $0, \mathrm{NS}$ ). However, when basal energy expenditure was expressed by reference to the $\mathrm{kg}$ free fat mass, a significant increase was found in the CLA group (123.3 (SEM 2.5) $\mathrm{kJ} / \mathrm{kg}$ free fat mass per d on day $98 v$. 118.7 (SEM $2.3) \mathrm{kJ} / \mathrm{kg}$ free fat mass per $\mathrm{d}$ on day $0, P=0.03$ ). On the contrary there was no change in the placebo group (120.4 
(SEM 2.2) $\mathrm{kJ} / \mathrm{kg}$ free fat mass per d on day $98 v .121 .6$ (SEM $2 \cdot 3) \mathrm{kJ} / \mathrm{kg}$ FFM per d on day 0, NS).

\section{Effects of conjugated linoleic acid supplementation on gene expression in adipose tissue}

The mRNA expression of candidate genes was determined in adipose tissue samples from twenty-one subjects: ten subjects from the CLA group and eleven subjects from the placebo group. Baselines characteristics were similar in these subgroups and consistent with those found in the entire CLA and placebo groups (data not shown). Figure 2 illustrates the variations in mRNA levels of LPL, HSL, PPAR and UCP-2 between day 0 and day 98 of the experimental protocol.

PPAR $\gamma$ mRNA expression increased significantly in the CLA group $(31.8 \mathrm{amol} / \mu \mathrm{g}$ total RNA at day $0 v .44 .4 \mathrm{amol} /$ $\mu \mathrm{g}$ total RNA at day $98, P<0.01)$ while it remained unchanged in the placebo group $(30 \cdot 1 \mathrm{amol} / \mu \mathrm{g}$ total RNA at day 0 v. $28.5 \mathrm{amol} / \mu \mathrm{g}$ total RNA at day 98 , NS). Moreover, the consumption of CLA-enriched yoghurt-like products induced a significant reduction in HSL mRNA levels in adipose tissue $(-42(\operatorname{SEM} 7) \%, P=0 \cdot 01)$, while the consumption of placebo yoghurt-like products did not significantly affect HSL mRNA level (49 (SEM 24) \%, NS). The levels of UCP2 mRNA were not altered during the trial, either in the CLA group (29 (SEM 13) \%, NS) or in the placebo group (3 (SEM 11) $\%$, NS). LPL mRNA expression was also not affected over the study period, either in the CLA group (25 (SEM 27) $\%, \mathrm{NS})$ or in the placebo group (-3 (SEM 16) \%, NS).

\section{Discussion}

Effects of conjugated linoleic acid on gene expression in adipose tissue

The present study presents the changes induced by the consumption of CLA-enriched dairy products in subcutaneous

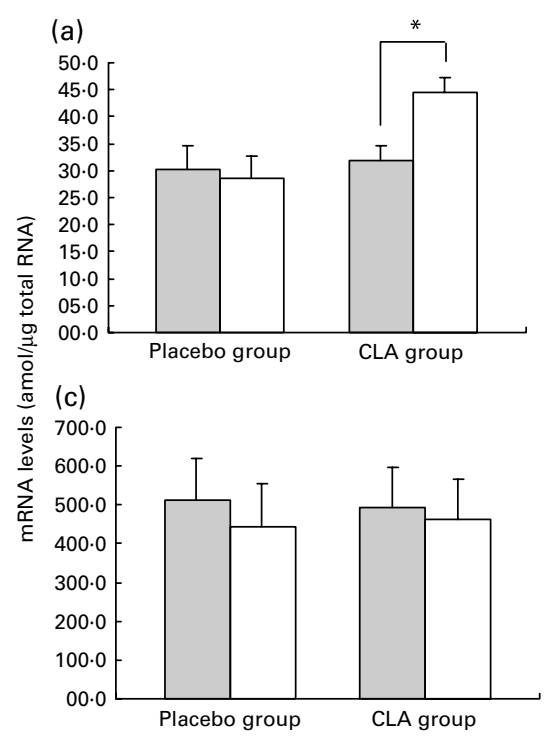

abdominal adipose tissue gene expression in healthy subjects. The in vivo changes in the expression of several key adipose tissue genes, including PPAR $\gamma$, LPL, a key enzyme in lipid metabolism that hydrolyses fatty acids from circulating triacylglycerols, UCP-2, a mitochondrial uncoupling protein that decreases ATP synthesis coupled to energetic substrates oxidation and HSL, the enzyme controlling lipolysis in white adipose tissue, were investigated. The $98 \mathrm{~d}$ CLA supplementation diet increased PPAR $\gamma$ gene expression and decreased HSL mRNA levels without any changes in LPL mRNA levels or in UCP-2 mRNA levels.

PPAR $\gamma$ is mainly expressed in adipose tissue and is a central regulator of adipocyte gene expression and differentiation (Lowell, 1999). Besides these effects, PPAR $\gamma$ plays a determinant role in body fat distribution (Lefebvre et al. 1998). Heterozygotous PPAR $\gamma$-deficient mice have a significant reduction in total body fat mass (Kubota et al. 1999). Recently, many studies have been designed to demonstrate the effects of CLA on PPAR $\gamma$ gene expression and on its downstream target genes. All were performed in animal models or using cultured human or murine adipocytes and, to our knowledge, no study on the regulation of gene expression by dietary intake of CLA has been performed in man. Tsuboyama-Kasaoka et al. (2000) reported important changes in gene expression in the adipose tissue of CLA-treated mice, including an increase in TNF $\alpha$ and UCP-2 mRNA expression and a decrease in PPAR $\gamma$, sterol regulatory element binding protein and fatty acid synthetase expression while LPL was unaffected. The changes were associated with a large decrease in adipose tissue weight and with an apoptosis state (Tsuboyama-Kasaoka et al. 2000). Such dramatic metabolic changes were not observed in the present experiment in man.

Some studies have shown a reduction in LPL activity caused by CLA supplementation and this effect was mainly allotted to the trans-10,cis-12 CLA isomer (Wang \& Jones, 2004). Kang et al. (2003) also showed that trans-10,cis-12 CLA inhibited the differentiation of preadipocytes and significantly inhibited the expression of PPAR $\gamma$ and its
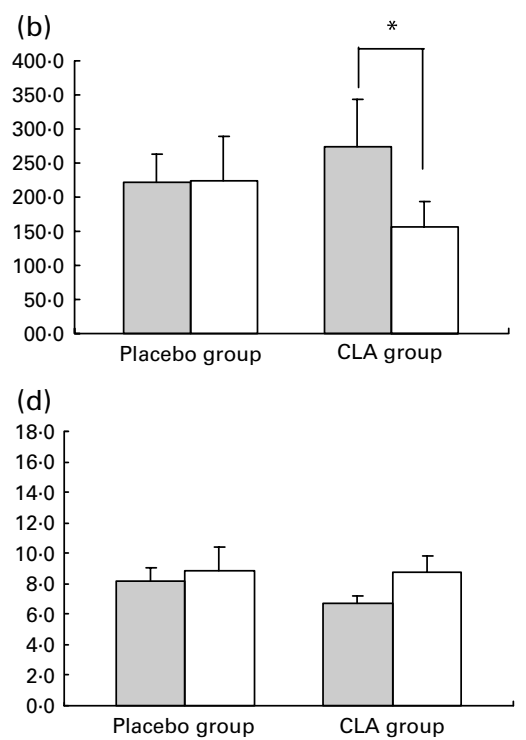

Fig. 2. Variations in mRNA levels of PPAR $\gamma(a)$, hormone-sensitive lipase (b), lipoprotein lipase (c) and uncoupling protein 2 (d) in adipose tissue between day 0 $(\square)$ and day $98(\square)$. For details of procedures, see Materials and methods section. Values are means with their standard errors depicted by vertical bars. There were no difference between groups at baseline. Mean values indicated were significantly different: ${ }^{\star} P<0 \cdot 01$. 
target LPL. In another study performed in mice (Takahashi et al. 2002), CLA decreased PPAR $\gamma$ mRNA levels in adipose tissue and more specifically in brown adipose tissue. It is interesting to note that the greatest effects were obtained in the mouse strain that was the most sensitive to diet-induced obesity. The present results were obtained using a 50:50 mixture of the two main isomers, trans-10,cis-12 and cis-9,trans-11. Again, this was associated with an important decrease in fat mass. Brown et al. (2003) observed the isomer-specific effects of CLA on gene expression in cultured adipocytes. Results showed that trans-10,cis-12 CLA decreased the expression of genes influencing differentiation: PPAR $\gamma$ and genes regulated by PPAR $\gamma$; whereas cis-9,trans-11 increased the expression of PPAR $\gamma$-dependent genes. Therefore, Brown et al. (2003) suggested that these mixed isomers might negate one another and so induce no change in adiposity or PPAR $\gamma$ expression. CLA isomers are also known to activate PPAR $\gamma$ with very low efficacy and another hypothesis proposed by Brown et al. (2003) was that CLA directly affects PPAR $\gamma$ activity by competing with other ligands with higher efficacy, and so the two isomers might mutually antagonize each other's activity. Therefore, discrepancies with other studies in regard to PPAR $\gamma$ gene expression could be related to the use of a mixture of the two isomers whose effects may have cancelled each other out.

In the present study, the determination of mRNA expression was performed in crude adipose tissue biopsies that have been taken before and at the end of the dietary supplementation of a CLA mixture containing $35 \%$ cis-9,trans-11 isomer and $35 \%$ trans-10,cis-12 isomer. Under such conditions, we observed significant changes in the expression of PPAR $\gamma$ and of HSL. These effects, however, were not associated with major changes in lipid metabolism during supplementation as illustrated by the lack of modification of plasma NEFA or triacylglycerol concentrations.

\section{Effects of conjugated linoleic acid on body composition and metabolism}

We found that the consumption of CLA-enriched dairy products providing $3.76 \mathrm{~g}$ CLA in triacylglycerols for $98 \mathrm{~d}$ did not alter body composition. The present result is different from those previously found in animals (Dugan et al. 1997; Park et al. 1999; Blankson et al. 2000; DeLany \& West, 2000; Kritchevsky et al. 2000; Stangl, 2000) and in man (Gaullier et al. 2004). However, it is consistent with the results obtained by Zambell et al. (2000), Medina et al. (2000), Malpuech-Brugère et al. (2004) and Pariza (2004). The differences between man and animals could be due to a dose effect since most studies in animals used higher doses per kg body weight. Another explanation can rely on a specie difference in metabolic rate since rodents generally have a higher metabolic rate than man. Also, as in many studies performed in man, dietary intake and activity in the present study were controlled but not standardized, which may interfere with the effects of CLA. Discrepancy in results between the human studies can be due to several differences in methodology and trial design. In fact, the duration of the trial (14 weeks, 1 year, etc.), the frequency (once a day, three times a day, etc.) and quantity of CLA intake, the way of administration and the food matrix containing CLA (associated diet, solution, capsules, triacylglycerols, enriched butter, enriched yogurtlike product, etc.), and the use of mixed or separate isomers could explained the variability of results found in human studies.

Importantly, the 14-week supplementation diet produced a significant increase in RMR in subjects. However, this observed increase in RMR was of low magnitude (about $3.76 \mathrm{~kJ} / \mathrm{kg}$ perd) and suggests that an effect on body weight might be obtained after a longer dietary intervention. In fact, $3.76 \mathrm{~kJ} / \mathrm{kg}$ per d represents for a $70 \mathrm{~kg}$ subject $263 \mathrm{~kJ}$ perd and $95995 \mathrm{~kJ}$ per year, if we assume the same increase in energy expenditure would be maintained for an entire year with CLA supplementation. Thus, $95995 \mathrm{~kJ}$ of energy expenditure represents $2.4 \mathrm{~kg}$ fat, that means a $70 \mathrm{~kg}$ subject from the CLA group would, in theory, lose $2.4 \mathrm{~kg}$ fat/year. In the study of Gaullier et al. (2004), the subjects lost $2.4 \mathrm{~kg}$ fat after 1 year of supplementation of $2.4 \mathrm{~g}$ CLA (triacylglycerols)/d. This confirms the calculated results; it might be therefore assumed that the duration of the trial was not long enough to produce a measurable reduction in body weight or fat mass, as in other studies in which no effects on body fat were observed. Maybe the body fat-lowering effect of CLA needs a long period of time to start and be effective. Another possible explanation for this change in energy expenditure not associated with a significant modification in body weight, fat mass or body composition could be a parallel increase in energy intake with CLA consumption. However, none of the subjects reported any modification in their daily food intake. Besides, such an explanation is not supported by literature data according to which CLA does not affect food intake or appetite in man (Medina et al. 2000; Terpstra, 2004). Therefore, we assume that a $98 \mathrm{~d}$ supplementation is not enough to obtain significant results in reducing body weight.

Regarding the mechanisms potentially involved in the observed change in the RMR, we did not find modification in the mRNA UCP-2 levels in adipose tissue. UCP participate in energy expenditure as possible candidates to explain mitochondrial proton leaks in skeletal muscle and adipose tissue (Ricquier \& Bouillaud, 2000). A positive correlation has previously been found between adipose tissue UCP-2 mRNA levels and RMR adjusted for lean body mass in obese women after diet standardization (Barbe et al. 1998). In a study by Takahashi et al. (2002), CLA supplementation greatly increased UCP-2 mRNA expression in brown adipose tissue in mice. However, in their study, the energy expenditure of the animals was not measured. So, further studies are required to understand the roles of UCP and energy expenditure with regard to CLA supplementation.

In most human studies, subjects were administered CLA orally in capsules, in the form of triacylglycerols or NEFA. In a recent study performed in overweight and obese men, CLA was incorporated into butter and the 4-week supplementation diet induced no beneficial effects either on total or HDL cholesterol, or on adipose tissue accumulation (Desroches et al. 2005). In the present study, measurements of both CLA isomer concentrations in blood after consumption of CLA-enriched yoghurt-like products demonstrate that concentrations increased following yoghurt-like product intake. So, administration of CLA once a day as triacylglycerols in a yoghurt seems to be a relevant way of administration, well tolerated and accepted by subjects. However, further 
pharmacokinetic studies should help to understand the specific effects of both CLA isomers on body composition as well as their bio-availability to optimise the way of administration.

In conclusion, a $98 \mathrm{~d}$ supplementation diet with a $50: 50$ mixture of the two CLA isomers cis-9,trans-11 and trans-10, cis-12 in a flavoured yoghurt-like product was unable to alter body composition, although a significant increase in the RMR could be recorded in the subjects of the CLA group. It seems therefore that the 14 weeks of the trial were not long enough to produce significant changes in body composition. We also found an effect of CLA supplementation on gene expression in adipose tissue, more specifically on PPAR $\gamma$. The observed increase in PPAR $\gamma$ gene expression is different from what could be expected from the results generally obtained in rodents or in vitro. This could be could be due to the use of mixed isomers. However, it is important to note that, to our knowledge, this is the first observation of CLA supplementation-induced gene expression in human tissues. Recent studies wondered about the potential detrimental effects of CLA, such as altered blood lipid composition or impaired insulin sensitivity. So, these points, as well as the specific effects of both CLA isomers, will require further investigation and longer nutritional interventions in order to understand fully the effects of CLA on body composition.

\section{References}

Auboeuf D \& Vidal H (1997) The use of the reverse transcriptioncompetitive polymerase reaction to investigate the in vivo regulation of gene expression in small tissue samples. Anal Biochem 245, 141-148.

Barbe P, Millet L, Larrouy D, Galitzky J, Berlan M, Louvet JP \& Langin D (1998) Uncoupling protein-2 messenger ribonucleic acid expression during very-low-calorie diet in obese premenopausal women. J Clin Endocrinol Metab 83, 2450-2453.

Binnert C, Pachiaudi C, Beylot M, Hans D, Vandermander J, Chantre P \& Laville M (1998) Influence of human obesity on the metabolic fate of dietary long and medium chain triacylglycerol. Am J Clin Nutr 67, 595-601.

Blankson H, Stakkestad JA, Fagertun H, Thom E, Wadstein J \& Gudmundsen O (2000) Conjugated linoleic acid reduces body fat mass in overweight and obese humans. J Nutr 130, 2943-2948.

Bligh E \& Dyer W (1995) A rapid method of total lipid extraction and purification. Can J Biochem Physiol 37, 911-917.

Brown JM, Boysen MS, Jensen SS, Morrison RF, Storkson J, Renee LC, Pariza M, Mandrup S \& McIntosh MK (2003) Isomer-specific regulation of metabolism and PPAR gamma signalling by CLA in human preadipocytes. J Lip Res 44, 1287-1300.

Brown JM \& McIntosh MK (2003) Conjugated linoleic acid in humans: regulation of adiposity and insulin sensitivity (Review). J Nutr 133, 3041-3046.

DeLany JP \& West DB (2000) Changes in body composition with conjugated linoleic acid. J Am Coll Nutr 4, 487S-493S.

Desroches S, Chouinard PY, Galibois I, Corneau L, Delisle J, Lamarche B, Couture P \& Bergeron N (2005) Lack of effect of dietary conjugated linoleic acids naturally incorporated into butter on the lipids profile and body composition of overweight and obese men. Am J Clin Nutr 82, 309-319.

Dugan MER, Aalhus JL, Schaefer AL \& Kramer JKG (1997) The effect of conjugated linoleic acid on fat to lean repartitioning and feed conversion in pigs. Can J Anim Sci 77, 723-725.
Fay L \& Richli U (1991) Location of double bonds in polyunsaturated fatty acids by gas chromatography-mass spectrometry after 4,4-dimethyloxazoline derivatization. J Chromatogr 541, 89-98.

Gaullier JM, Halse J, Hoye K, Kristiansen K, Fagertun H, Vik H \& Gudmundsen O (2004) Conjugated linoleic acid supplementation for $1 \mathrm{y}$ reduces body fat mass in healthy overweight humans. Am J Clin Nutr 79, 1118-1125.

Grandlund L, Juvet LK, Pedersen JI \& Nebb HI (2003) Trans10, cis12-conjgated linoleic acid prevents triacylglycerol accumulation in adipocytes by acting as a PPAR gamma modulator. J Lipid Res 44, 1441-1452.

Kamphuis MM, Lejeune MP, Saris WH \& Westerterp-Plantenga MS (2003) The effect of conjugated linoleic acid supplementation after weight loss on body weight regain, body composition, and resting metabolic rate in overweight subjects. Int J Obes Relat Metab Disord 27, 840-847.

Kang K, Liu W, Albright KJ, Park Y \& Pariza MW (2003) Trans-10, cis-12 CLA inhibits differentiation of 3T3-L1 adipocytes and decreases PPAR gamma expression. Biochem Biophys Res Commun 303, 795-799.

Kritchevsky D, Tepper SA, Wright S, Tso P \& Czarnecki SK (2000) Influence of conjugated linoleic acid (CLA) on etablishment and progression of atherosclerosis in rabbits. J Am Coll Nutr 4, 472-477S0.

Kubota N, Terauchi Y, Miki H, et al. (1999) PPAR gamma mediates high-fat diet-induced adipocyte hypertrophy and insulin resistance. Mol Cell 4, 597-609.

Laville M, Auboeuf D, Khadfallah Y, Vega N, Riou JP \& Vidal H (1996) Acute regulation by insulin of phosphatidylinositol-3-kinase, Rad, Glut4 and lipoprotein lipase mRNA levels in human muscle. J Clin Invest $\mathbf{9 8}, 43-49$.

Lavillonnière F, Martin JC, Bougnoux P \& Sebedio J-L (1998) Analysis of conjugated linoleic acid isomers and content in French cheeses. J Am Oil Chem Soc 75, 343-352.

Lefebvre M, Laville M, Vega N, Riou JP, Van Gaal L, Auwerx J \& Vidal H (1998) Depot-specific differences in adipose tissue gene expression in lean and obese subjects. Diabetes 47, 98-103.

Lin H, Boylston TD, Chang MJ, Luedecke LO \& Schultz TD (1995) Survey of the conjugated linoleic acid contents of dairy products. J Dairy Sci 78, 2358-2365.

Lowell BB (1999) PPARgamma: an essential regulator of adipogenesis and modulator of fat cell function. Cell 99, 239-242.

Malpuech-Brugère C, Verboeket-van de Venne WP, Mensink RP, et al. (2004) Effects of two conjugated linoleic acid isomers on body fat mass in overweight humans. Obes Res 12, 591-598.

Medina EA, Horn WF, Keimn NL, Havel PJ, Benito P, Kelley DS, Nelson GJ \& Erickson KL (2000) Conjugated linoleic acid supplementation in humans: effect on circulating leptin concentrations and appetite. Lipids 35, 783-788.

Pariza MW (2004) Perspective on the safety and effectiveness of conjugated linoleic acid. Am J Clin Nutr 79, Suppl. 6, 1132S-1136S.

Pariza MW, Park Y \& Cook ME (2000) Mechanisms of action of conjugated linoleic acid: evidence and speculation. Proc Soc Exp Biol Med 223, 8-13.

Park Y, Storkson JM, Albright KJ, Liu W \& Pariza MW (1999) Evidence that the trans-10,cis-12 isomer of conjugated linoleic acid induces body composition changes in mice. Lipids $\mathbf{3 4}$, 235-241.

Park Y, Storkson JM, Liu W, Albright KJ, Cook ME \& Pariza MW (2004) Structure-activity relationship of conjugated linoleic acid and its cognates in inhibiting heparin-releasable lipoprotein lipase and glycerol release from fully differentiated 3T3-L1 adipocytes. $J$ Nutr Biochem 15, 561-568.

Richard MJ, Portal B, Meo J, Coudray C, Hadjian A \& Favier A (1992) Malondialdehyde evaluated for determining plasma and lipoprotein fractions that react with thiobarbituric acid. Clin Chem 38, 704-709. 
Ricquier D \& Bouillaud F (2000) Mitochondrial uncoupling proteins: from mitochondria to the regulation of energy balance. $J$ Physiol 529, $3-10$

Riserus U, Vessby B, Arnlov J \& Basu S (2004) Effects of cis-9, trans-11 conjugated linoleic acid supplementation on insulin sensitivity, lipid peroxidation, and proinflammatory markers in obese men. Am J Clin Nutr 80, 279-283.

Ryder JW, Portocarrero CP, Song XM, et al. (2001) Isomer-specific antidiabetic properties of conjugated linoleic acid. Improved glucose tolerance, skeletal muscle insulin action, and UCP-2 gene expression. Diabetes 50, 1149-1157.

Smedman A \& Vessby B (2001) Conjugated linoleic acid supplementation in humans - metabolic effects. Lipids 36, 773-781.

Stangl GI (2000) Conjugated linoleic acids exhibit a strong fat to lean partitionning effect, reduce serum VLDL lipids and redistribute tissue lipids in food restricted rats. J Nutr 130, 1140-1146.

Takahashi Y, Kushiro M, Shinohara K \& Ide T (2002) Dietary conjugated linoleic acid reduces body fat mass and affects gene expression of proteins regulating energy metabolism in mice. Comp Biochem Phys B Biochem Mol Biol 133, 395-404.

Terpstra AH (2004) Effects of conjugated linoleic acid on body composition and plasma lipids in humans: an overview of the literature. Am J Clin Nutr 79, 352-361.

Terpstra AH, Beynen AC, Everts H, Kocsis S, Katan MB \& Zock PL (2002) The decrease in body fat in mice fed conjugated linoleic acid is due to increases in energy expenditure and energy loss in the excreta. J Nutr 132, 940-945.
Tricon S, Burdge GC, Williams CM, Calder PC \& Yaqoob P (2005) The effects of conjugated linoleic acid on human health-related outcomes. Proc Nutr Soc 64, 171-182.

Tsuboyama-Kasaoka N, Takahashi M, Tanemura K, Kim HJ, Tange T, Okuyama H, Kasai M, Ijemoto S \& Ezaki O (2000) Conjugated linoleic acid supplementation reduces adipose tissue by apoptosis and develops lipodystrophy in mice. Diabetes $\mathbf{4 9}$, $1534-1542$

Vidal H, Auboeuf D, De Vos P, Staels B, Riou JP, Auwerx J \& Laville M (1996) The expression of ob gene is not acutely regulated by insulin and fasting in human abdominal subcutaneous adipose tissue. J Clin Invest 98, 251-255.

Wang Y \& Jones PJ (2004) Dietary conjugated linoleic acid and body composition. Am J Clin Nutr 79, 1153s-1158s.

Wargent E, Sennit MV, Stocker C, Mayes AE, Brown L, O'dowd J, Wang S, Einerhand AW, Mohede I, Arch JR \& Cawthorne MA (2005) Prolonged treatment of genetically obese mice with conjugated linoleic acid improves glucose tolerance and lowers plasma insulin concentration: possible involvment of PPAR activation. Lipids Health Dis 10, 3.

West DB, Delany JP, Camet PM, Blohm F, Truett AA \& Scimeca J (1998) Effects of conjugated linoleic acid on body fat and energy metabolism in the mouse. Am J Physiol 275, R667-R672.

Zambell KL, Keim NL, Van Loan MD, Gale B, Benito P, Kelley DS \& Nelson GJ (2000) Conjugated linoleic acid supplementation in humans: effect on body composition and energy expenditure. Lipids 35, 777-782. 